\title{
Conservation Strategy of Rafflesia zollingeriana Koord in Meru Betiri National Park, East Java
}

\author{
Dewi Lestari $^{1 *}$, Agus Hikmat ${ }^{2}$, Ervizal Amir Muhammad Zuhud ${ }^{2}$ \\ 'Graduate School of Bogor Agricultural University, Dramaga Main Road, Campus IPB Dramaga, Bogor, Indonesia 16680 \\ ${ }^{2}$ Department of Forest Resource Conservation and Ecotourism, Faculty of Forestry, Bogor Agricultural University, \\ Academic Ring Road, Campus IPB Dramaga, PO Box 168, Bogor, Indonesia 16680
}

Received September 16, 2013/Accepted March 20, 2014

\begin{abstract}
Rafflesia zollingeriana Koorders is a protected, rare, and endemic plants to Meru Betiri National Park. However, its population was declined. So, the study was focused on the analysis of the strengths, weaknesses, opportunities, and threats of conservation of R. zollingeriana to recommend some conservation's strategy and programs. This study was conducted at Meru Betiri National Park and its surrounding 5 villages. Data were collected by interviews, survey, observations, and literature studies. Qualitative data was analyzed by reduction, presentation and drawing conclusions simultaneously, while the quantitative data was analyzed descriptively. Matrix for SWOT analysis was processed by SPSS 16. The result showed that there were 4 elements that identified as strength, 5 elements that identified as weakness, 5 elements that identified as opportunity and 4 elements that identified as threat. The internal factor's value was higher than the external factor. The result of the SWOT analysis indicated that it needs aggresive strategy through collaboration among stakeholders to optimize both strength and opportunites. While the recommended program are: socialization the importance of $R$. zollingeriana conservation and developing $a$ collaborative R. zollingeriana ecotourism.
\end{abstract}

Keywords: collaboration, ecotourism, stakeholder, SWOT analysis

*Correspondenceauthor, email: itisme.dewi@gmail.com,tel.: +62-81310273690;fax.: +62-3682033170

\section{Introduction}

Rafflesia spp is an unique plant because of its large flowers and its presence that only realized when the buds exist and blooming. It was only holoparasit to Tetrastigma spp. (Barkman et al. 2004; Barcelona et al. 2011). Rafflesia spp. is rare because of its small population (Nais 2001). Populations of $R$. lobata in Mount Igtuog Philippines only 76 individuals (Galang \& Madulid 2006). R. manillana population in Mount Makiling is also just 86 individuals (Yahya et al. 2010). Populations of R. arnoldi at 5 locations in West Sumatra only 80 individuals (Syahbuddin \& Chairul 2010). Population of R. patma in Leweung Sancang, consist of 96 individuals (Suwartini et al. 2008).

Rafflesia's small population is caused by biological nature and ecological attributes (Susatya 2003), such as low reproductive rate (Nais 2001). From the 1,110 buds were observed by Nais (2001) in 3 years, only $10.18 \%$ that succeed to bloome while the proportion of female flowers only $12.39 \%$ and the fruit succeeded only $35.71 \%$. The unbalanced sex ratio also indicated by Galang (2006) in $R$. lobata population. In addition, low reproduction occur because rafflesia is an unisexual (Meijer 1997; Refaei et al. 2011), so its pollination needs insects assistance (Zuhud et al. 1999; Davis et al. 2008; Kahono et al. 2010) and so does its seed dispersal (Bouman \& Meijer 1994; Kahono et al. 2010).
Small population is also caused by its low survival ability. Hidayati et al. (2000) founded R. patma in Pangandaran that consist of $44 \%$ died knobs, $49 \%$ alive buds, and $7 \%$ blooming flower. Thousands of rafflesia that observed by Nais in Malaysia also showed high death rate before blooming until 90\% (Milius 1999).

External factors such as fragmentation and habitat destruction were also pressured rafflesia's small population. R. patma population in Leweung Sancang was decreased, from 256 individuals (Priatna et al. 1989) in 5 areas to 96 individuals in 9 areas due to logging and deforestation (Suwartini et al. 2008). While population R. banahaw in the Philippines declined because of landslides and typhoons (Barcelona et al. 2007).

There were 30 species of rafflesia that successfully described. The recent rafflesia that successfully described were $R$. aurantia (Barcelona et al. 2009), R. meijeri (Wiriadinata \& Sari 2010), R. verrucosa (Balete et al. 2010), and $R$. lawangensis (Matt-Salleh et al. 2010). The possibility of a new species description is widely open but racing with its extinction.

Among of those 30 species, 16 species are distributed in Indonesia. R. patma, $R$. rochussenii and $R$. zollingeriana are distributed in Java Island. $R$. zollingeriana less distributed than the other two species. It was only distributed in Betiri 
Meru National Park (MBNP) and only grows in dry lowland forest, at an altitude of $1-270 \mathrm{~m}$ above sea level. $R$. zollingeriana was known with the local names patmosari. It was used for traditional medicine and collected ilegally by the local people (Zuhud 1989), so its population is vulnerable to extinction.

Rafflesia is able to live in primary and secondary forests (Zuhud 1989; Syahbudin \& Chairul 2010). Therefore, to sustaining its population, the forest ecosystem should be save in a primary state. Thus, save rafflesia will increase the motivation to save the whole ecosystem.

Conservation status of $R$. zollingeriana is rare (Wiriadinata 2001) or R (rare) by WCMC (2013). While Susatya (2011) categorized it to CR (critical endangered). Rafflesia spp. also designated as a protected plant in Indonesia according to Government Regulation No. 7/1999. By Betiri Meru National Park Authority (MBNPA). $R$. zollingeriana has been designated as a species whose habitat is protected and nurtured (BTNMB 2003). However, reality showed that $R$. zollingeriana in TNMB population continues to decline. In 1988, the population of rafflesia found in 8 locations, while in 2003, the population can only be found in 3 locations (Hikmat 2006).

Along with its declining populations, there is a challenge ie: lack of its scientific information. So, the population of $R$. zollingeriana should be saved for research and assessment study. This is in accordance with the principle "Save it, Study it and Use it" in the Convention on the Conservation of Biodiversity. An ecosystem or a species has to saved before extinct and assessment of its usefulness should be done for the improvement of human welfare (Putro et al. 2012). The effective strategy to maintain the sustainability of $R$. zollingeriana population is required. This strategy can be formulated if the strengths, weaknesses, opportunities, and threats that have been made during the conservation are identified and evaluated.

\section{Methods}

The study was conducted at Meru Betiri National Park and 5 villages surrounding (Wonoasri, Curahnongko, Andongrejo, Sanenrejo, and Sarongan), during January to December 2012. Data were collected by interviews, surveys, observations, and literature study. Interviews were conducted to MBNPA staff, academist, activists nature lovers, non government organization (NGO) activists, and government staff. While the survey was conducted to 157 local people that living in MBNP and its surrounding. These respondents are dominated by farmer (61.15\%). Observations carried out in Sukamade and Krecek permanent plots. Qualitative data was analyzed by reduction, presentation, and drawing conclusions simultaneously. Quantitative data analyzed descriptively. SWOT analysis conducted by identifying the internal and external factors, then weighting, ranking and scoring of each elements (Maintindom et al. 2006). SWOT matrix to determine strategy is processed by SPSS 16 .

\section{Results and Discussion}

Meru Betiri Management at the 1970s until 1996 more focused on the protection and preservation for the java tiger than $R$. zollingeriana conservation. There was no specific regulation that ruled knob collection activity, so the sustainability of the $R$. zollingeriana was threatened. After became a national park and run by MBNPA, monitoring of $R$. zollingeriana and habitat protection (BTNMB 2003) are started. Data collection and routine observations in Krecek and Sukamade plots also being conducted and published in a book (Darmadja et al. 2011). In 2010, R. zollingeriana habitat in Krecek and Sukamade were made into permanent plots for education, research, and nature tourism. Railings, stairs, signage, and information boards about $R$. zollingeriana were built on the plot. Guiding from MBNPA officers were also given for visiting tourists. The existence of $R$. zollingeriana as a tourism attraction also socialized in MBNPA's brochures and website.

However, those conservation efforts are still dominated by MBNPA. Interviews showed no involvement from the other stakeholders and the R.zollingeriana tourism did not developed optimally. Number of visiting tourists was still low. From 640,492 visiting tourists to Jember (BPS 2011) and 443,938 to Banyuwangi (BPS 2011), visiting number to MBNP only 4,402 tourists $(85.85 \%$ of them are domestic tourists). The visitor number of $R$. zollingeriana was predicted much lower. The survey respondents who knew that $R$. zollingeriana can be visited by tourist only reached $29.94 \%$ and the number of respondents who involved in this tourism activity only $12.10 \%$.

Table 1 showed that populations of $R$. zollingeriana in TNMB were decline. Therefore, more effective strategies of $R$. zollingeriana conservation should be formulated through SWOT analysis.

Table 1 Number of $R$. zollingeriana in observation plots

\begin{tabular}{|c|c|c|c|c|c|c|}
\hline $\begin{array}{c}\text { Time of } \\
\text { Research }\end{array}$ & $\begin{array}{c}\text { Number of } \\
\text { Plots }\end{array}$ & $\begin{array}{l}\text { Number of } R \text {. } \\
\text { zollingeriana }\end{array}$ & Means & Minimum & Maximum & $\begin{array}{l}\text { Standard } \\
\text { deviation }\end{array}$ \\
\hline $1988^{5}$ & 8 & 171 & 21.375 & 2 & 68 & 23.3846 \\
\hline $1989^{6}$ & 10 & 202 & 20.2 & 10 & 32 & 8.1076 \\
\hline $2012^{7}$ & 19 & 152 & 8 & 1 & 19 & 5.2810 \\
\hline
\end{tabular}

1) Hikmat (1988) in Lestari (2013); 2) Zuhud (1989); 3) Lestari (2013). Number of plots above are variated because the wide of forest area that has been explored by researchers are variated (Figure 2). Plots was purposively made based on $R$. zollingeriana existence at the observation. 
SWOT analysis SWOT analysis is needed to identify and evaluate internal and external factors of $R$. zollingeriana conservation. Identification results showed that there were 4 elements of $R$. zollingeriana conservation strength, such as:

1 MBNP is a habitat for endemic $R$. zollingeriana

$R$. zollingeriana is an unique rare and endemic species in MBNP (Darmadja et al. 2011). With its limited distribution, $R$. zollingeriana was more deserved to be a priority of conservation than the other species. This species conservation will also increase motivation to conserve the whole ecosystem in MBNP (Zuhud 1988)

$2 R$. zollingeriana is an endangered plant

There were some laws underlied $R$. zollingeriana conservation management today. Such as Law No. $5 / 1990$ on Conservation of Natural Resources and Ecosystems; Law No. 41/1999 on Forestry; Government Regulation No. 7/1999 about Plant and Animal Species Preservation, and IUCN Red List (Nais 2001)

3 Conservation of $R$. zollingeriana potential to enhance local people's prosperity.

Rafflesia conservation in Malaysia can enhance prosperity of local people (Nais 1998). So did the ecotourism of $R$. arnoldii in West Sumatra (Ekawati 2001). If $R$. zollingeriana ecotourism in MBNP is also developed with local people involvement like those cases above, their prosperity will also increase gradually

4 Legal basis of MBNPA as a manager authority of MBNP. There are some basic laws that underlied MBNPA as manager authority of MBNP: the regulation of the Minister of Forestry of the Republic of Indonesia Number P.03/Menhut-II/2007 about the Organization and Administration of National Parks; Regulation of the Minister of Forestry of the Republic of Indonesia Number P.48/Menhut-II/2010 about Natural Resources Tourism in Asylum Areas, National Parks, Forest Parks and Nature Park

While the weakness of the $R$. zollingeriana conservation were:

1 Limitness quality and quantity of MBNPA staff MBNPA have a limited number of officers but large area of responsibility, so $R$. zollingeriana conservation was not performed optimally. They documented observation data irregularly, their inventories are still limited and without involving the local people. Habitat maintenance of $R$. zollingeriana in in Krecek and Sukamade permanent plots wasn't performed as the standard operating procedures

2 Low attention to $R$. zollingeriana conservation

This is demonstrated by the low budget for conservation of $R$. zollingeriana. In 2011 , MBNPA used $1.397 \%$ of their total budget for monitoring $R$. zollingeriana (BTNMB 2011). This budget is smaller than the wildlife conservation budget that reached $6.904 \%$

3 Lack of law enforcement

Although there is a Government Regulation No. 7/1999 about Rafflesia spp., but laws enforcement is lacking. There is no operation rule that stated about $R$. zollingeriana specifically, so the ilegal collectors of $R$. zollingeriana knobs are handling informally. The $R$. zollingeriana knobs trading in Banyuwangi market still remains (LATIN 2002) and there has been no formal handling and control efforts to its traders and manufacturers

4 The low survival rate and regeneration of $R$. zollingeriana Hikmat (1988) stated that he found 34\% knobs of $R$. zollingeriana in dead condition. This showed that the death rate $R$. zollingeriana also as high as the other species. But unfortunately, research about $R$. zollingeriana survivality has not been done, so the solution has not been found yet

5 Lack capacity of MBNPA to promote collaboration with the other stakeholders

It can be seen from the percentage of survey respondents who knew about $R$. zollingeriana conservation activity that only amounted to $26.11 \%$ and the low level of involvement of respondents which only amounted to $7.64 \%$. Interviews with the private sector, NGOs, organizations and other agencies also showed their lack involvement in the conservation efforts. Collaboration with another stakeholders is a key for MBNPA to overcome their internal problem and optimize the $R$. zollingeriana conservation

Meanwhile, there are 5 things that identified as an opportunity from external factors to $R$. zollingeriana conservation, such as:

1 MBNPlied in the tourism path

MBNP lies between Yogyakarta and Bali, 2 favorite tourist destinations. Tourist arrival in Jember and Banyuwangi are quite high, amounting to 1,084,430 tourist. Existing tourist facilities ie accommodation, consumption, tourist guiding, and interpretation in the MBNP were sufficient in quantity and quality.

2 Huge number of local people

The population of 5 villages around and inside the national park is 33,233 people. This huge number can be used to overcome the limited staff of MBNPA if their participation is enabled. Local people have to be involved because their live are connected and depend on MBNP sustainability.

3 A large number of universities, conservation cadre, nature lovers, and NGOs that could be involved in conservation.

There are more than 30 universities, NGOs, and nature lovers community in Jember and Banyuwangi that concern to MBNP conservation. They also concerned that $R$. zollingeriana is an unique flora that close to extinct and they have desire to get involved in the conservation of $R$. zollingeriana.

4 Local people and stakeholder willingness to involve in $R$. zollingeriana conservation

The survey showed that $74.52 \%$ of respondents want to involve in the next conservation of $R$. zollingeriana. MPNPA have to accomodate their willingness and arrange some stakeholder analysis to identify which people or stakeholder that going to be an active or a passive participant.

5 High attention to conservation topic

Currently, conservation became a popular theme in the world, especially with the issue of global warming. There a lot of local, national, and global organization that interested in this issue and have the funding to further 
engage. This can be used as an alternative to overcome limited funds of $R$. zollingeriana conservation.

While the threats faced by $R$. zollingeriana conservation are:

1 The low level of public knowledge

Surrounding communities have limited knowledge about $R$. zollingeriana. Although most of respondents (64.33\%) knew that $R$. zollingeriana is protected, but they did not know its life cycle and reproduction. They did not know that unselected knob collection activity will lead $R$. zollingeriana to extinct.

$2 R$. zollingeriana habitat lies closely to the residential community

There are a lot enclaves in the national park. Some of their residence are close to $R$. zollingeriana habitat. If they did not involved in $R$. zollingeriana conservation, they did not know the importance of its conservation to their life and did not get any economic benefit from it, they tend to disobey it and exploit its knobs as before. Although knob collecting activity are decrease significantly now, but it is a temporary condition. If the knob price getting higher as before, those activity will rise again and the sustainability of $R$. zollingeriana populations will being threatened.

3 Low income levels and lower productivity of agricultural activities in the rehabilitation land

Most of the local people surrounding of MBNP are peasants. So, their live are so depend to forest especially with the MBNP rehabilitation program that allowed them to do shifting cultivation in deforestation land. This activities adding their total revenue up to $21.45 \%$ (Suharti 2004). But this percentage is expected to be smaller and smaller because productivity of the seasonal agricultural decreases. If their revenue was lower and lower, the possibility to re-gather of $R$. zollingeriana knob will rise again.

4 The remaining request of $R$. zollingeriana for traditional medicine

Demand of knob $R$. zollingeriana for herbs still remaining. In Banyuwangi market, $R$. zollingeriana traded at IDR20,000 $\mathrm{kg}^{-1}$ (LATIN 2002). Actually, the population will stay sustainably if the collection only done on died knobs.

Strategy and program recommendation for the next $\boldsymbol{R}$. zollingeriana conservation Measurement of the internal and external factors are displayed in Table 2. It shows the internal factors and external factors are positive, but the internal factor's value is higher than the external factors. The matrix in Figure 1 shows that the intersection between the $\mathrm{x}$ axis (internal factors) and the y-axis (external factors) lied in $1^{\text {st }}$ quadrant. So, the strategy should be taken is an aggressive

Table 2 IFAS dan EFAS of $R$. zollingeriana conservation in Meru Betiri National Park

\begin{tabular}{|c|c|c|c|c|}
\hline IFAS and EFAS & Weigth & Rating & Score & Total value \\
\hline \multicolumn{5}{|l|}{ IFAS } \\
\hline \multicolumn{5}{|l|}{ Strength } \\
\hline - TNMB is an endemic habitat for $R$. zollingeriana & 0.2 & 4 & 0.8 & \\
\hline $\begin{array}{l}\text { - R. zollingeriana is an protected rare plants and a trigger to conserve the whole } \\
\text { ecosystem in MBNP }\end{array}$ & 0.1 & 4 & 0.4 & \\
\hline - R. zollingeriana potential to enhance local people prosperity & 0.1 & 4 & 0.4 & 1.8 \\
\hline - Legal basis management of MBNP that run by MBNPA & 0.1 & 2 & 0.2 & \\
\hline \multicolumn{5}{|l|}{ Weakness } \\
\hline - Low attention of MBNPA to $R$. zollingeriana conservation & 0.05 & 4 & 0.2 & \\
\hline - Limited number and quality of MBNPA staff & 0.1 & 2 & 0.2 & \\
\hline - Lack of law enforcement & 0.05 & 4 & 0.2 & \\
\hline - R. zollingeriana ability to survive and bloom are low & 0.1 & 1 & 0.1 & 0.9 \\
\hline - Lack capacity of MBNPA to promote collaboration with another stakeholder & 0.2 & 1 & 0.2 & \\
\hline \multicolumn{5}{|l|}{ EFAS } \\
\hline \multicolumn{5}{|l|}{ Opportunity } \\
\hline - Location of MBNP in the path of tourism & 0.2 & 4 & 0.8 & \\
\hline - Huge number of local people surrounding & 0.05 & 2 & 0.1 & \\
\hline $\begin{array}{l}\text { - Huge number of universities, lover's nature and NGO that can be involved in } \\
R \text {. zollingeriana conservation }\end{array}$ & 0.1 & 3 & 0.3 & \\
\hline $\begin{array}{l}\text { - Local people and stakeholder willingness to involve in } R \text {. zollingeriana } \\
\text { conservation }\end{array}$ & 0.1 & 3 & 0.3 & 1.55 \\
\hline - Conservation becomes a world's concern now & 0.05 & 1 & 0.05 & \\
\hline \multicolumn{5}{|l|}{ Threats } \\
\hline - Limited knowledge of local people about $R$. zollingeriana & 0.2 & 1 & 0.2 & \\
\hline - R. zollingeriana habitat are close to residential of local people & 0.1 & 2 & 0.2 & \\
\hline $\begin{array}{l}\text { - Low income levels of local people and their agricultural productivity in the } \\
\text { rehabilitation areas are lower and lower }\end{array}$ & 0.1 & 3 & 0.3 & 0.9 \\
\hline - R. zollingeriana request for traditional medicine is remaining & 0.1 & 2 & 0.2 & \\
\hline
\end{tabular}

IFAS = Internal Factor Analysis Summary; EFAS= External Factor Analysis Summary 


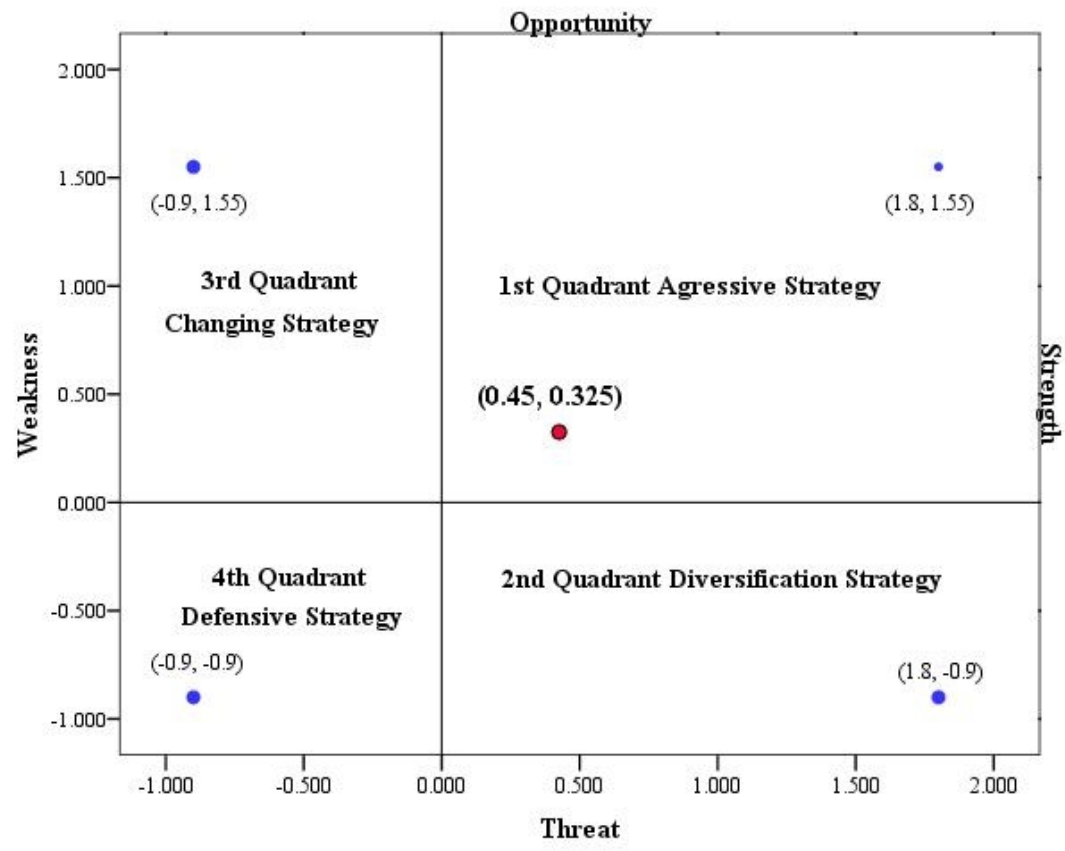

Figure 1 SWOT matrix of $R$. zollingeriana conservation in Meru Betiri National Park.

strategy: optimizing the strength so that opportunities can be optimally utilized. This strength can be optimized through collaboration with the other stakeholders.

Next conservation programs that recommended are:

1 Socialization the importance of $R$. zollingeriana conservation to increase stakeholders awareness

Collaboration with community, other agencies, and organizations are needed to optimize conservation. To establish collaboration, mutual trust, mutual respect and mutual benefit among stakeholders are needed (Putro et al. 2012). Stakeholders will collaborate if you already have an equivalent knowledge and understanding of the importance of conservation of $R$. zollingeriana. So the importance of $R$. zollingeriana conservation must be socialized massively through various mass media in international, national, and local level.

At the local level, MBNPA have to hold a workshop that discussing the ecologic and economic benefit of $R$. zollingeriana conservation. This meeting involves local people, the rafflesia researcher, nature lover organization, local government, and relevant agencies such as BKSDA, local forestry services, local agency of tourism department, etc. Information about the blooming $R$. zollingeriana must been arranged in many medias, such as audiovisual media (local and national TV broadcasting) and social networks like facebook, twitter, instagram, and youtube. This information have to available in Indonesian and foreign languages. $R$. zollingeriana should be an icons and identity flora of the MBNP to increase stakeholders awareness. It is worth to be MBNPA logo, complements javan tiger logo, because of its scarcity and endemism reason.

2 Developing a collaborative $R$. zollingeriana ecotourism
$R$. zollingeriana ecotourism have to involve the local people. If the local people get a higher income from $R$. zollingeriana, their motivation to sustain its populations of will increase. It is like what happened in Malaysia (Nais 1998). Ecotourism considered have more economic benefit than the other utilization. Revenue from the knobs collection is IDR $10,000 \mathrm{~kg}^{-1}$ dry knob. While the revenue from homestay service and tourist guiding is about IDR200,000 people day $^{-1}$.

Local people participation is possible because their willingness to involve in this tourism activity is high $(74.52 \%)$. However, only $51.59 \%$ of them who know how to develop the $R$. zollingeriana ecotourism. Therefore, participation other stakeholders: private (tourist practitioner: travel agencies), NGOs, and the department of tourism, who are experienced in the planning and implementation of tourism programs are needed. They are needed to participate in local people capacity building. To develop ecotourism, MPNPA staff and local people competence need to be improved with some English language training, hospitality tourism training, souvenirs manufacture training, and $R$. zollingeriana training.

Information about $R$. zollingeriana blooming, especially when it can be visited must be updated regularly in MBNP's website. So does with the visiting procedures i.e. list of do and do not do at site. This information should be accessed any time. Contact number enlisted in website www.merubetiri.com must be contacted freely, both in the Indonesian and foreign language. Permanent plots must be furnished with a complete and interesting information so the visitor can get comprehensive information even they can not see $R$. zollingeriana blooming directly. 


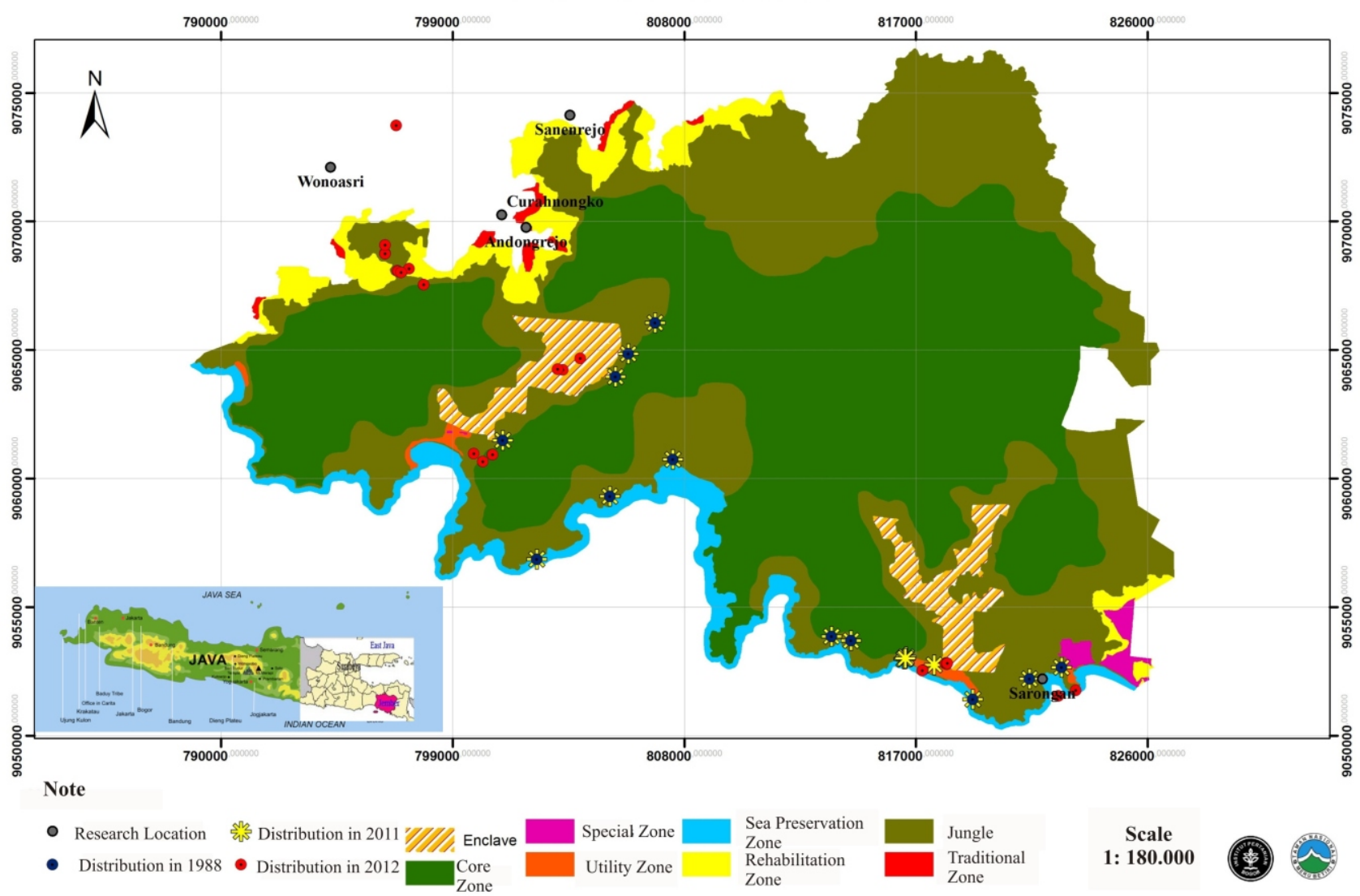

Figure 2 Distribution of Rafflesia zollingeriana Koord in Meru Betiri National Park (Lestari 2013).

\section{Conclusion}

SWOT analysis showed that internal factor's value was higher than the external factor. Strategy that need to be developed is an aggressive strategy, optimizing strength through collaboration so that opportunities can be utilized optimally. While the recommended program are: socialization the importance of of $R$. zollingeriana conservation and developing a collaborative $R$. zollingeriana ecotourism.

\section{Acknowledgements}

Thanks given to MBNPA who facilitating and providing information. Thanks also given to Ellyn K Damayanti, $\mathrm{PhD}$. Agr for allowing me to take a part at her rafflesia project that funded by the Toyota Foundation.

\section{References}

Balete DS, Pelser PB, Nickrent DL, Barcelona JF. 2010. Rafflesia verrucosa (Rafflesiaceae), a new species of small-flowered Rafflesia from eastern Mindanao, Philippines. Phytotaxa 10:49-57.

Barcelona JF, Pelser PB, Cajano MO. 2007. Rafflesia banahaw (Rafflesiaceae) a new species from Luzon, Philippines. Blumea 52:345-350. http://dx.doi.org/ $10.3767 / 000651907 X 609089$.

Barcelona JF, Co LL, Balete DS, Bartolome NA. 2009. Rafflesia aurantia (Rafflesiaceae): a new species from northern Luzon, Philippines. Singapore Gardens' Bulletin 61:17-27.

Barcelona JF, Fernando ES, Nickrent DL, Balete DS, Pelser PB. 2011. An amended description of Rafflesia leonardi and a revised key to philippine rafflesia (Rafflesiaceae). Phytotaxa 24:1-18.

Barkman TJ, Lim SH, Mat Salleh K, Nais J. 2004. Mitochondrial DNA sequences reveal the photosynthetic relatives of rafflesia, the world's largest flower. PNAS 101(3):787-792. http://dx.doi.org/10.1073/pnas.03055 62101 .

[BTNMB] Balai Taman Nasional Meru Betiri. 2003. Laporan Pembinaan Habitat R. zollingeriana $K d s$ di Taman Nasional Meru Betiri. Jember: Kemenhut Dirjen PHKA-BTNMB. 
[BTNMB] Balai Taman Nasional Meru Betiri. 2011. Laporan Hasil Pelaksanaan Anggaran 2011 Taman Nasional Meru Betiri. Jember: Kemenhut Dirjen PHKABTNMB.

[BPS] Badan Pusat Statistik. 2011. Kabupaten Banyuwangi dalam Angka. Banyuwangi: BPS Banyuwangi.

[BPS] Badan Pusat Statistik. 2011. Kabupaten Jember dalam Angka. Jember: BPP Kabupaten Jember-BPS Jember.

Bouman F, Meijer W. 1994. Comparative structure of ovules and seeds in Rafflesiaceae. Plant Systematics and Evolution 193:187-212. http://dx.doi.org/10.1007/ BF00983550.

Davis CC, Endress PK, Baum DA. 2008. The evolution of floral gigantism. Current Opinion in Plant Biology 11:49-57. http://dx.doi.org/10.1016/j.pbi.2007.11.003.

Darmadja B, Guntoro DA, Rohmah N, Atmodjo ND, Ananda AA. 2011. Buku Informasi Bunga Rafflesia di Taman Nasional Meru Betiri. Jember: BTNMB.

Ekawaty R. 2001. Conservation Status of Rafflesia arnoldi R.Br. in Gunung Sago Halaban Regency Limapuluh Kota Sumatera Barat [thesis]. Bogor: Bogor Agricultural University.

Galang R, Madulid DA. 2006. A second new species of rafflesia (Rafflesiaceae) from Panay Island, Philippines. Folia malaysiana 7(1\&2):1-8.

Galang R. 2007. Population study of Rafflesia lobata in the northern section of central Panay Island mountain ranges, Philippines. Folia malaysiana 8(2):87-98.

Hidayati SN, Willem M, Jeffrey LW. 2000. A contribution to the life history of the rare Indonesian holoparasite Rafflesia patma (Rafflesiaceae). Biotropica 32(3):408-414.

Hikmat A. 2006. Population trend of R. zollingeriana Kds. in Meru Betiri National Park, East Java. Media Konservasi 11(3):105-108.

Kahono S, Mursidawati S, Erniwati. 2010. Insect community on ex-situ Rafflesia patma Blume (Rafflesiaceae) in Bogor Botanical Garden, Bogor, West Java. Journal Indonesian Biology 6(3):429-442.

LATIN. 2002. Inventarisasi, Identifikasi dan Pemetaan Potensi Wanafarma. Bogor: LATIN.

Lestari D. 2013. Conservation of Rafflesia zollingeriana Koord in Meru Betiri National Park [thesis]. Bogor: Bogor Agricultural University.

Maintindom Y, Indrawan A, Kartodihardjo H. 2006. Analysis of land resource management policies on Cycloop Mountains Nature Reserve. Journal Manajemen Hutan Tropika 12(3):58-71.
Matt-Salleh K, Mahyuni R, Susatya A, Veldkamp JF. 2010. Rafflesia lawangensis (Rafflesiaceae), a new species from Bukit Lawang, Gunung Leuser National Park, North Sumatra, Indonesia. Reinwardtia 13(2):159-169.

Meijer W. 1997. Rafflesiaceae. Flora Malesiana 1(13):1-42.

Milius S. 1999. The science of big, weird flowers: some of the best things in botany come in large packages. Science News 156(11):172. http://dx.doi.org/10.2307/4011823.

Nais J, Wilcock CC. 1998. The rafflesia conservation incentive scheme in Sabah, Malaysian Borneo. Sabah Parks Nature Journal 1:9-17.

Nais J. 2001. Rafflesia of The World. Kota Kinabalu: Sabah Park.

Priatna DR, Zuhud EAM, Alikodra HS. 1989. Ekologic study on Rafflesia patma Blume in Leweung Sancang Nature Reserve, West Java. Media Konservasi 2(2):1-7.

Putro HR, Supriatin, Sungkar A, Rossanda D, Prihatini ER. 2012. Pengelolaan Kolaboratif Taman Nasional di Indonesia. Bogor: JICA-CFET.

Refaei J, Jones EBG, Sakayaroj J, Santhanam J. 2011 Endophytic fungi from Rafflesia cantleyi: species diversity and antimicrobial activity. Mycosphere 2(4):429-447.

Suharti S. 2004. Social forestry implementation in rehabilitation land in Meru Betiri National Park-East Java. Journal of Forest Research and Nature Conservation 1(3):345-355.

Susatya A. 2003. Population and rare plant life cycle of Rhizanthes loweii. (Becc) Harm (Rafflesiaceae) in Kerinci-Seblat National Park Katenong Resort. Journal of Indonesian Agricultural Sciences 5(2):71-76.

Susatya A. 2011. Rafflesia Pesona Bunga Terbesar di Dunia. Jakarta: Direktorat Kawasan Konservasi dan Bina Hutan Lindung.

Suwartini R, Hikmat A, Zuhud EAM. 2008. Vegetation condition and population of Rafflesia patma Blume di Leweung Sancang Nature Reserve. Media Konservasi. 13(3):1-8.

Syahbuddin, Chairul. 2010. Populasi dan periodisasi pembungaan serta habitat genetik padma raksasa $(R$. arnoldii R Br.) di Sumatra Barat. Working Paper Fakultas MIPA. http://repository.unand.ac.id/1332/ [9 Mei 2013].

Wiriadinata H. 2001. Tumbuhan. In: Noerdjito M, Maryanto I, editor. Spesies-Spesies Hayati yang Dilindungi Perundang-undangan Indonesia. Bogor: Balitbang Zoologi-Puslitbang Biologi-LIPI dan The Nature Conservacy. 
[WCMC] World Conservation Monitoring Centre. UNEP Species Database. http://www.unep-wcmc-apps.org/ $\mathrm{isdb} /$ Taxonomy/tax-genus-result.cfm?habit=\&display language $=$ ENG $\&$ Genus $=8096 \&$ Gen $=\&$ source $=$ plants $\&$ Country $=$ [3 Juni 20133].

Wiriadinata H, Sari R. 2010. A new spesies of Rafflesia (Rafflesiaceae) from North Sumatra. Reinwardtia 13(2):95-100.

Yahya AF et al. 2010. Distribution pattern, reproductive biology, cyotaxonomis study and conservation of Rafflesia manillana in Mt. Makiling, Laguna, Philippines. Journal of Tropical Forest Science 22(2):118-126.
Zuhud EAM. 1988. Environment of Rafflesia zollingeriana Kds in Meru Betiri National Park. Media Konservasi. 2(1):25-30.

Zuhud EAM. 1989. Ecologic study of R. zollingeriana Kds in Meru Betiri National Park, East Java [thesis]. Bogor: Bogor Agricultural University.

Zuhud EAM. 1989. Strategy of biodiversity conservation and utility of Indonesian medicinal plants. Media Konservasi 2(4):1-7.

Zuhud EAM, Hernidiah N, Hikmat A. 1999. Conservation of Rafflesia hasseltii Suringar di Bukit Tigapuluh Riau National Park-Jambi. Media Konservasi 6(1):23-26. 